\title{
The effect of enterprise resource planning on the organizational performance of organizations through HRM practices An Applied Study on the Reinforcing Steel Sector Companies in Egypt
}

\author{
Ahmed Atries \\ Aiman A. Ragab \\ Mohamed A. Ragheb \\ Mohamed Wahba \\ Arab Academy for Science, Technology and Maritime Transport
}

\begin{abstract}
Keyword
Balanced Scorecard, Enterprise Resource Planning, Human Resource Management, Organizational Performance.
\end{abstract}

\begin{abstract}
This research aims to study the impact of Enterprise Resource Planning (ERP) (information quality, system quality and system use) and human resource management (HRM) practices (training and development, information exchange, recruitment and testing, compensation and benefits, safety and health and employee relations) on organizational performance. Through the Balanced scorecard (financial performance, customer performance, supplier performance and employee performance) in the rebar sector companies within the Arab Republic of Egypt. Therefore, the researcher used the positivism philosophy in this study and the deductive approach because they are more compatible with the nature of the research and with what the researcher wants to reach. He also followed a quantitative method in collecting data, as he prepared a questionnaire and distributed it to 260 individuals working in the reinforcing steel sector.

The data is analyzed using some statistical methods such as: correlation, and the structural equation model. The results fully accept the study hypotheses that there is a statistically significant relationship between ERP and organizational performance through the balanced scorecard. In addition to, relationship between ERP and HRM practices, moreover, relationship between HRM practices and organizational performance through the balanced scorecard. While it partially accepts that here is a statistically significant role for HRM practices, in the relationship between ERP and organizational performance through the Balanced Scorecard.
\end{abstract}

\section{Introduction}

Organizations are facing an increase in global competition, and these organizations have no other options but to be more effective to keep pace with the changes in competition. Every organization has its vision, mission, and strategy, and the organizational performance through the Balanced Scorecard is a management system that aims to help the organization achieve its objectives, as the Balanced Scorecard allows for the evaluation of the organization's performance in a balanced and comprehensive manner. AlNajjar and Kalaf (2012) aimed to identify the importance of the balanced scorecard and study the dimensions on which it is based, try to apply it, explain how it is used in evaluating the performance of the institution, as it is considered a modern tool in the performance evaluation process of the organization. And it relied on the descriptive approach in the theoretical side in addition to personal interviews and the collection of information provided by the institution. Among its most prominent results is that the evaluation of financial performance is considered necessary for the organization because it gives a quick and comprehensive picture of the actual performance of the organization, as it enables to know the strengths to strengthen them and to know the weaknesses to avoid them. In addition to considering the balanced scorecard as one of the most important tools used in evaluating performance, as its goal is to achieve the highest possible level of business number, so we find it strives to maintain its customers by satisfying them and acquiring new customers.

Based on previous studies, it was found that one of the factors that affect organizational performance through the balance card is ERP through human resource management practices. Thus, the research will 
discuss the impact of ERP and human resource performance practices on organizational performance through the Balanced Scorecard.

It is worth noting that many large companies have implemented new information systems under the name of Organization Resource Planning (ERP) systems in response to global changes, the most important of which is the increase in global competition. Reasonable time. The applications of ERP systems include, supply chain management (SCM), customer relationship management (CRM), product life cycle management (PLM), electronic procurement and financial management), and ERP systems can also integrate company operations and help organizations to Achieving competitive advantage, including improving productivity, obtaining a competitive advantage, satisfying customer needs, and increasing their ability to respond.

The ERP systems provide solutions by providing departments with mechanisms of clarification and more transparency for all the processes that take place in the organization, and it also aims to enhance and improve the competitiveness of the organization by improving the ability of the organization to generate information with extreme accuracy and provide it in a timely manner. It is worth noting that ERP is a process that companies use to manage and integrate important parts of their business, and it is also preparing many of the important ERP software applications for companies because it affects human resources by integrating all the processes necessary to operate their companies in one system. Enterprises integrate all essential business processes in order to enhance efficiency and maintain a competitive position. This research deals with it were concluded that there are positive effects of ERP on organizational performance through the Balanced Scorecard, which ultimately leads to improving the overall performance of companies.

\section{Literature Review}

In the following sections, resource planning in the organization and human resource management practices and their impact on organizational performance will be explained through the Balanced Scorecard, as organizational or institutional performance is considered a dependent variable where human resource management practices play a mediating role in the relationship between resource planning in the organization and its impact on organizational performance. With the Balanced Scorecard. Previous studies dealing with and clarifying these relationships are presented and the theoretical basis for the conceptual framework is presented, explaining the methodological aspects of these studies.

\section{The Relationship between Enterprise Resource Planning and Organizational Performance}

This section deals with the relationship between ERP and organizational performance through some studies that the researcher dealt with in studying this relationship over the years. Anderson et al. (2011) sought to know the effect of ERP on organizational performance. Where the data relied on collecting financial data from Compustat, and data on the start date and end date of ERP implementation between 1990 and 2005 for companies in the oil and gas industry. Among the most prominent findings was that ERP had a positive effect on organizational performance. Al-Dhaafri and Al-Swidi (2014) indicated the extent of the role of ERP to improve organizational performance. To examine the assumed study form, data were collected from the department officers in Dubai Police. The survey questionnaire was used as a way to collect data, 111 questionnaires were valid for analysis and testing of the hypotheses. The results confirmed that the implementation of ERP had a positive and significant impact on organizational performance.

Shen et al. (2016) emphasized the relationship between ERP and organizational performance. The data collected using questionnaires sampling from high-tech companies that have implemented ERP systems over the past three years (such as SAP, Oracle, Baan, JDEdwards, SSA, etc.). After that, the hierarchical dimensions of the balanced scorecard (BSC) were developed to measure the ERP performance of each company and its impact on the strategic objectives. The results found that ERP had a positive effect on organizational performance.

However, Saleh and Thoumy (2018) sought to know the extent of the impact of ERP on organizational performance. The data collected relied on a questionnaire to collect the size and type of company for each respondent. In the first section of the questionnaire, general information about the respondent, his background and the company he works for are analyzed. The results indicated that the ERP units had a 
positive variable effect on organizational performance. Based on the previous studies that had been circulated, the researcher could assume the first hypothesis, which is that there is a statistically significant relationship between ERP and organizational performance.

H1: There is a Statistically Significant Relationship between ERP and Organizational Performance

\section{The Relationship between Enterprise Resource Planning and Human Resource Management Practices}

This section deals with the relationship between ERP and human resource management practices through some studies that the researcher dealt with in studying this relationship over the years. Guimaraes et al. (2015) aimed to test the impact of implementation of ERP on human resource management practices (HRMP). To reach and verify a goal, a questionnaire form was used, where the required data were collected through a questionnaire from a group of project managers for ERP projects. Where the most prominent results were to conclude that the human aspects related to the implementation of ERP are very important and can explain a large part of the change in the system's effect on end-user jobs and thus make HRMP work effectively and hence the importance of application of the ERP system to HRMP. Kushwaha et al. (2018) aimed to measure the impact of ERP on human resource management and compared its effectiveness regarding ERP on human resource management. The required data were collected from three companies, Shriram Pistons and Rings Ltd., Bosch and Tata of Automobile Sector. As the size of the sample in the research consists of 80 samples, including the companies that had been mentioned. As one of the most prominent results was that there was a statistically significant relationship between Enterprise Resource Planning (ERP) and Human Resources Management (HRMP). Moreover, the human resource information system helped the organization to make the decision when training and skills development was necessary.

Widjaja et al. (2019) aimed to study the models and indicators used to evaluate the implementation of the enterprise resource planning (ERP) system and its impact on human resource management (HRM) practices in higher education institutions. In order to verify the main aim, study and evaluate the implementation of the ERP system in the organization and its impact on the human resource management practices in higher education institutions. The data required to achieve the goal was collected by distributing questionnaires to 32 respondents and analyzing these collected data afterwards and performing a validity and reliability test. Thus, the results showed the extent of the correlation of resource planning in the organization from the quality of the system, the quality of information and the use of the system and its impact on human resource management practices from training and development, information exchange, recruitment and selection, compensation and benefits, safety and health and employee relations.

Based on previous studies that have been circulated, the researcher can assume the second hypothesis of the study, which is that there is a statistically significant relationship between enterprise resource planning and human resource management practices.

H2: There is a Statistically Significant Relationship between Enterprise Resource Planning and Human Resource Management Practices

\section{The Relationship between Human Resource Management Practices and Organizational Performance}

This section deals with the relationship between human resource management practices (HRMP) and organizational performance through some studies that the researcher dealt with in studying this relationship over the years.

Quresh et al. (2010) aimed to clarify the relationship between HRMP and the financial performance of banks in Pakistan. The employee. Thus, 46 Pakistani banks were contacted, and the response was from 38 banks. The results came to prove that there was a positive relationship between all the variables under study and the financial performance of banks, and that the performance of banks should focus on these four variables, as they were mandatory.

Subramaniam et al. (2011) aimed to determine the relationship between the main dimensions of HRMP and the organizational performance of the institution. To this end, a survey was conducted on small and medium organizations in the central region of Peninsular Malaysia, where the questionnaire was sent to 200 organizations who were willing to do it and it was sent specifically to human resource 
managers or the owner of the organization, and after two weeks, 84 were returned. The result came to prove the existence of a positive relationship between all dimensions (except job security) of HRM and organizational performance.

Hassan et al. (2013) contributed to researching the impact of human resource practices on employee satisfaction and employee loyalty in the banking sector in Pakistan. The data were collected from employees of five public banks, out of 210 distributed questionnaires answered, it got a total of 177 valid answers. The results concluded that there was a close correlation and positive relationship between human resource practices, employee satisfaction and employee loyalty in the banking sector.

Al-Tit (2016) clarified the relationship between HRMP and organizational performance for Jordanian industrial companies. A total of 300 questionnaires were sent by e-mail to managers at different administrative levels, rounds yielded 247 valid questionnaires for analysis to test the relationship hypotheses. Among the most prominent findings was that HRMP had a significant direct positive impact on organizational performance.

Wikhamn (2019) revealed how sustainable HRMP affect the relationship between innovation and customer satisfaction. Where the data relied on an online questionnaire to a sample of hotels registered as members of the Swedish Hospitality Industry Organization, 195 managers representing 195 organizations participated in the survey. The results indicated that the relationship between innovation and customer satisfaction depended on sustainable human resource practices in the organization, although innovation and sustainable human resource practices positively affect customer satisfaction, their interaction indicated that one of them can replace the other to achieve superior customer satisfaction. The results found that sustainable human resource practices enhanced the hotel's ability to innovate and satisfy customers.

Based on the previous studies that have been circulated, the researcher can assume the third hypothesis of the study, which is that there is a statistically significant relationship between HRPM and organizational performance.

H3: There is A Statistically Significant Relationship between Human Resource Management Practices and Organizational Performance

\section{The Role of HRMP in the Relationship Between ERP on Organizational Performance Through the Balanced Scorecard}

This section deals with the role of human resource management practices in the relationship between resource planning in the organization on organizational performance through the balanced scorecard through some studies that the researcher has dealt with in studying this relationship over the years. Lin (2015) aimed to know the effect of ERP on the Balanced Scorecard card (BSC), where it was found that there were several dimensions that affect the BSC. The researcher was studied using the quantitative approach through a questionnaire by collecting data from 244 managers responsible for knowledge management projects in their companies. The results concluded that there was a strong relationship between ERP and BSC. Results also showed that ERP had an impact on the four dimensions that affect BSC, and that the four dimensions of BSC were important for company managers to improve overall organizational performance.

Albrecht et al. (2015) aimed to support the model that demonstrates how employee participation and performance, whether individual or collective, can be integrated within the human resource management fabric of an organization if the goal is to seek a sustainable competitive advantage. It followed the descriptive and analytical approach using surveys to address the research topic. These results had a positive impact that will help organizations achieve a competitive advantage. Parto et al. (2016) aimed to know the impact of the implementation of ERP on the financing performance of companies and the impact of the model that was developed to study this relationship between ERP and financial performance. This study conducted a survey on companies and data was collected and analyzed. The results of the experimental analysis of the extracted data indicated that the complete implementation of the ERP system in the enterprise in all its aspects leads to a positive impact on the performance of the company's financial affairs. 
Kushwaha et al. (2018) aimed to study the effect of ERP on HRM. it also explained that the productivity of any organization is through the HRM and its effective management, the application of information technology such as ERP integrates many business processes and information systems. The data relied on preliminary data gathered through a structured questionnaire distributed on three companies: Tata and Rings. Ltd Bosch and Shrirman pistons for the automotive sector. The results concluded that ERP had a significant positive impact on HRM for these companies.

Khan (2019) aimed to find out the effect of ERP on operational effectiveness, communication process, HRMP and measuring the impact on performance. Financial performance and to prove the objective, a survey was conducted among employees, where the most prominent results were to prove the existence of a positive relationship between resource planning in the organization on its organizational performance and to achieve this goal, there was a need for an effective and trained work team to operate the ERP system.

Based on previous studies that have been circulated, the researcher can assume the fourth hypothesis of the study, which is that there is a statistically significant role for human resource management practices in the relationship between enterprise resource planning and organizational performance through the balanced scorecard.

H4: There is a Statistically Significant Role for Human Resource Management Practices in the Relationship Between Enterprise Resource Planning and Organizational Performance through the Balanced Scorecard

\section{Research Methodology}

This study aims to examine the impact of enterprise resource planning (information quality, system quality, system use) and human resource management practices (training and development, information exchange, recruitment and testing, compensation and benefits, safety and health, employee relations) on organizational performance through the scorecard Balanced (financial performance, customer performance, supplier performance, employee performance). To test this goal, the researcher used the positivism philosophy in this study and the deductive approach because they are more compatible with the nature of the research and with what the researcher wants to reach. Consequently, the data required to test the objective was collected through quantitative data issued from the questionnaire that was distributed to collect the required data from the sample to finally arrive at a study of the effect of enterprise resource planning on organizational performance through the mediator role that human resource management practices play in this relationship. The variables used in this study can be categorized into Three main types which are the dependent and independent and moderating variables.

Independent Variable: Enterprise Resource Planning (information quality, system quality and system use).

Dependent Variable: Organizational performance through the Balanced Scorecard (financial performance, customer performance, supplier performance and employee performance).

Moderating variables: Human resource management practices (training and development, information exchange, recruitment and testing, compensation and benefits, safety and health and employee relations).

Figure 1, represents the proposed study model for this research, where the study aimed at the variables: 
Research Analysis and Findings

The researcher in this section tests the hypotheses of the research, which is that there is a moral relationship between research variables. First, the study starts with Validity and Reliability Tests. Second, Descriptive analysis is used to data. Third, the researcher performs the normality testing in order to find out if the data is subject to the normal distribution or not. Finally, regression assumption is conducted.

Figure 1:Research Framework

Testing the First Hypothesis of the Relationship between ERP and Organizational Performance

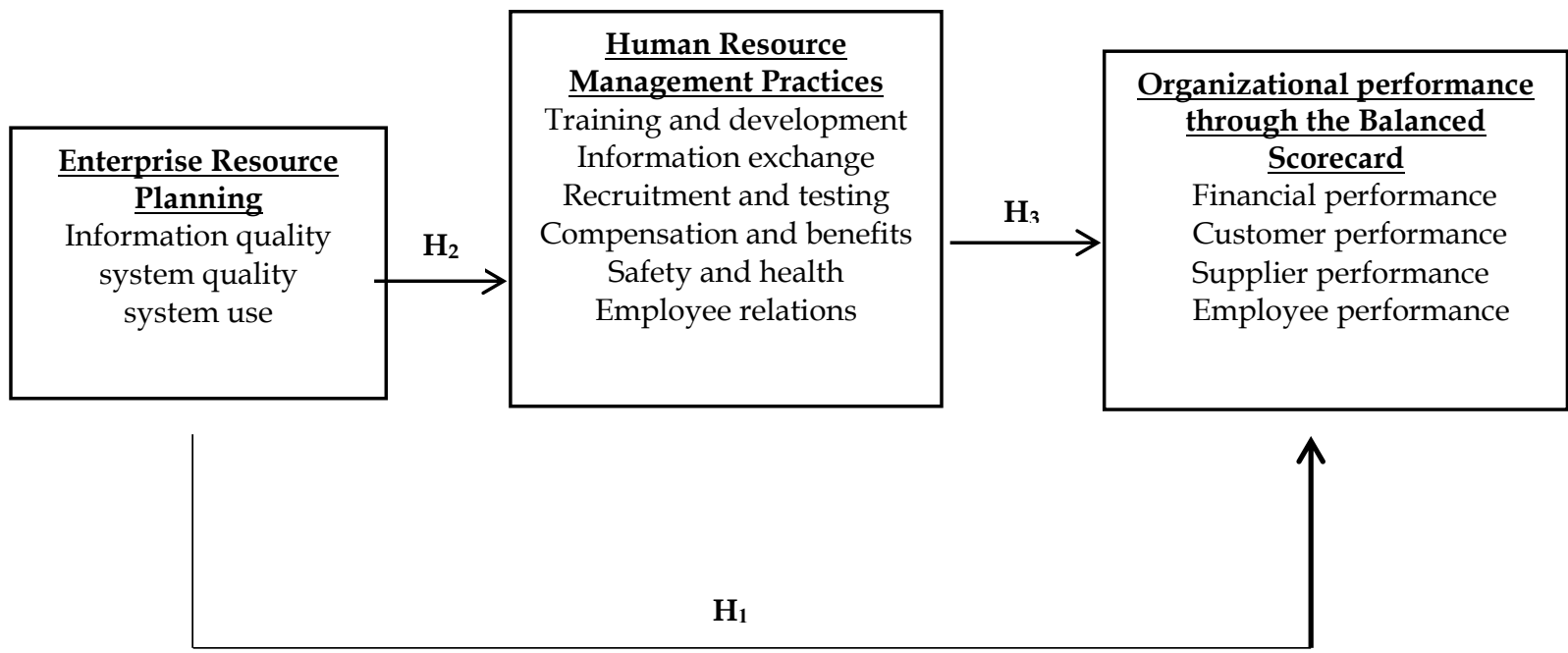

The correlation coefficient between enterprise resource planning was tested, including: (information quality, system quality, and system use) and financial performance. It was found that there is a positive statistically significant correlation between the quality of information, the quality of the system, the use of the system, and the financial performance as the values of the correlation coefficient are $0.496,0.473$, and 0.427 , respectively, and the significance level is less than 0.05 .

The correlation coefficient between enterprise resource planning was tested, including: (information quality, system quality, and system use) and internal operation. It was found that there is a positive statistically significant correlation between the quality of information, the quality of the system, the use of the system, and the internal operations, as the values of the correlation coefficient are $0.387,0.345$, and 0.354 , respectively, and the level of significance is less than 0.05 .

Table 1 shows the multiple regression model for enterprise resource planning, including (information quality, system quality, and system use) and their impact on the dependent variable, which is financial performance. Financial performance as the significance level values is less than 0.05 and the regression coefficient values are $0.280,0.287$, and 0.177 , respectively. Moreover, its $\mathrm{R}$ Square value is 0.317 , which means that $31.7 \%$ of financial performance can be explained by information quality, system quality, and system utilization.

In addition, Table 1 shows the multiple regression model for enterprise resource planning, including (information quality, system quality, and system use) and their impact on the dependent variable, which is internal operation. The researcher found that there is a positive significant effect for both information quality, system quality, and system usage on internal operation, where the significance level values are less than 0.05 and the regression coefficient values are $0.197,0.147$, and 0.188 , respectively. Moreover, its $\mathrm{R}$ Square value is 0.200 , which means that $20 \%$ of internal operations can be explained by information quality, system quality, and system utilization. 
Table 1: Regression Analysis for Enterprise Resource Planning on Financial Performance and Internal Operation

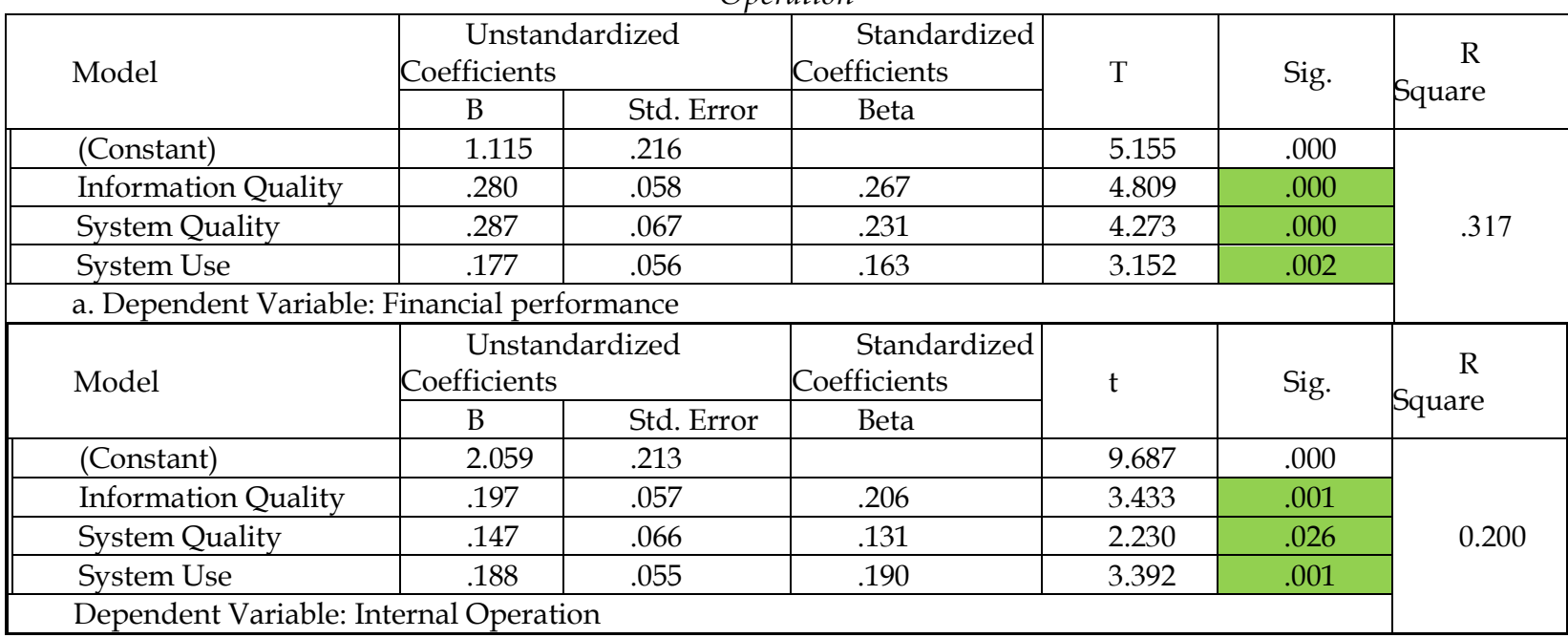

Based on the previous results, it can be seen that the first sub-hypothesis of the first hypothesis "There is a statistically significant relationship between enterprise resource planning and financial performance" is fully acceptable.

Based on the previous results, it can be seen that the second sub-hypothesis of the first hypothesis, "There is a statistically significant relationship between enterprise resource planning and internal operations" is fully acceptable.

The correlation coefficient between enterprise resource planning was tested, including: (information quality, system quality, and system use) and learning and growth. It was found that there is a positive statistically significant correlation between the quality of information, the quality of the system, the use of the system, and learning and growth as the values of the correlation coefficient are $0.427,0.396$, and 0.429, respectively, and the level of significance is less than 0.05 .

The correlation coefficient between enterprise resource planning was tested, including: (information quality, system quality, and system use) and customer satisfaction. It was found that there is a positive statistically significant correlation between the quality of the information, the quality of the system, the use of the system, and the customer's satisfaction, as the values of the correlation coefficient are 0.360 , 0.355 , and 0.365 respectively, and the level of significance is less than 0.05 .

Table 2 shows the multiple regression model for resource planning for organizations, including (information quality, system quality, and system use) and their impact on the dependent variable, which is learning and growth. The researcher found that there is a positive significant effect for both information quality, system quality, and system usage on Learning and growth as the significance level values are less than 0.05 and the regression coefficient values are $0.214,0.174$, and 0.272 , respectively. Moreover, its $R$ Square value is 0.263 , which means that $26.3 \%$ of learning and growth can be explained by information quality, system quality, and system usage.

In addition, Table 2 shows the multiple regression model for enterprise resource planning, including (information quality, system quality, and system usage) and their impact on the dependent variable, which is customer satisfaction. Customer satisfaction as the significance level values is less than 0.05 and the regression coefficient values are $0.137,0.172$, and 0.206 , respectively. Moreover, its R Square value is 0.193 , which means that $19.3 \%$ of customer satisfaction can be explained by information quality, system quality, and system utilization. 
Table 2: Regression Analysis for Enterprise Resource Planning on Learning and Growth and Customer Satisfaction

\begin{tabular}{|c|c|c|c|c|c|c|}
\hline \multirow{3}{*}{ Model } & \multirow{2}{*}{\multicolumn{2}{|c|}{$\begin{array}{l}\text { Unstandardized } \\
\text { Coefficients }\end{array}$}} & \multirow{3}{*}{\begin{tabular}{|c|c}
$\begin{array}{c}\text { Standardized } \\
\text { Coefficients }\end{array}$ \\
Beta \\
\end{tabular}} & \multirow{3}{*}{$\mathrm{t}$} & \multirow{3}{*}{ Sig. } & \multirow{3}{*}{$\begin{array}{r}\mathrm{R} \\
\text { Square }\end{array}$} \\
\hline & & & & & & \\
\hline & \begin{tabular}{|c|}
$\mathrm{B}$ \\
\end{tabular} & Std. Error & & & & \\
\hline (Constant) & 1.277 & .221 & & 5.788 & .000 & \multirow{5}{*}{.263} \\
\hline Information Quality & .214 & .059 & 207 & 3.594 & .000 & \\
\hline System Quality & .174 & .069 & .143 & 2.544 & .011 & \\
\hline System Use & .272 & .057 & .254 & 4.739 & .000 & \\
\hline \multicolumn{6}{|c|}{ a. Dependent Variable: Learning and Growth } & \\
\hline \multirow{2}{*}{ Model } & \multicolumn{2}{|c|}{$\begin{array}{l}\text { Unstandardized } \\
\text { Coefficients }\end{array}$} & $\begin{array}{l}\begin{array}{l}\text { Standardized } \\
\text { Coefficients }\end{array} \\
\end{array}$ & \multirow{2}{*}{$\mathrm{t}$} & \multirow{2}{*}{ Sig. } & \multirow{2}{*}{$\begin{array}{c}\mathrm{R} \\
\text { Square }\end{array}$} \\
\hline & B & Std. Error & Beta & & & \\
\hline (Constant) & 1.986 & .207 & & 9.592 & .000 & \multirow{4}{*}{.193} \\
\hline Information Quality & .137 & .056 & .148 & 2.447 & .015 & \\
\hline System Quality & .172 & .064 & .157 & 2.669 & .008 & \\
\hline System Use & .206 & .054 & .215 & 3.819 & .000 & \\
\hline
\end{tabular}

Based on the previous results, it can be seen that the third sub-hypothesis of the first hypothesis, "There is a statistically significant relationship between enterprise resource planning and learning and growth" is fully acceptable.

Based on the previous results, it can be seen that the fourth sub-hypothesis of the first hypothesis "There is a statistically significant relationship between enterprise resource planning and customer satisfaction" is fully acceptable. Based on these results, the first hypothesis "there is a statistically significant relationship between enterprise resource planning and organizational performance through the balanced scorecard" is fully acceptable.

Testing the Second Hypothesis of the Relationship between Enterprise Resource Planning and Human Resource Management Practices

The correlation coefficient between enterprise resource planning was tested, including: (information quality, system quality, and system use) and training and development. It was found that there is a positive statistically significant correlation between the quality of information, the quality of the system, the use of the system, and training and development, as the values of the correlation coefficient are 0.420 , 0.392 , and 0.479 , respectively, and the significance level is less than 0.05 .

The correlation coefficient between enterprise resource planning was tested, including: (information quality, system quality, and system use) and information exchange. It was found that there is a positive statistically significant correlation between the quality of information, the quality of the system, the use of the system, and the exchange of information, as the values of the correlation coefficient are $0.512,0.443$, and 0.469 , respectively, and the significance level is less than 0.05 .

Table 3 shows the multiple regression model for resource planning for organizations, including (information quality, system quality, and system use) and their impact on the dependent variable, which is training and development. The researcher found that there is a positive significant effect for both information quality, system quality, and system usage on Training and development, where the significance level values are less than 0.05 and the regression coefficient values are $0.118,0.136$, and 0.274 , respectively. Moreover, its $\mathrm{R}$ Square value is 0.287 , which means that $28.7 \%$ of training and development can be explained by information quality, system quality, and system utilization.

In addition, Table 3 shows the multiple regression model for enterprise resource planning, including (information quality, system quality, and system use) and their impact on the dependent variable, which is information exchange. The researcher found that there is a positive significant effect for both the quality of information, the quality of the system, and the use of the system on Information exchange, where the significance level values are less than 0.05 and the regression coefficient values are $0.291,0.189$, and 0.229 , respectively. Moreover, the value of $\mathrm{R}$ Square is 0.349 , which means that $34.9 \%$ of the information exchange can be explained by information quality, system quality, and system usage. 
Table 3: Regression analysis of enterprise resource planning on training and development and Information

\begin{tabular}{|c|c|c|c|c|c|c|}
\hline \multirow[t]{2}{*}{ Model } & \multicolumn{2}{|c|}{$\begin{array}{l}\text { Unstandardized } \\
\text { Coefficients }\end{array}$} & \multirow{2}{*}{\begin{tabular}{|c|}
$\begin{array}{c}\text { Standardized } \\
\text { Coefficients }\end{array}$ \\
Beta \\
\end{tabular}} & \multirow[t]{2}{*}{$\mathrm{T}$} & \multirow[t]{2}{*}{ Sig. } & \multirow{2}{*}{$\begin{array}{r}\mathrm{R} \\
\text { Square }\end{array}$} \\
\hline & $\mathrm{B}$ & Std. Error & & & & \\
\hline (Constant) & 1.861 & .167 & & 11.121 & .000 & \multirow{5}{*}{.287} \\
\hline Information Quality & .118 & .045 & .149 & 2.622 & .009 & \\
\hline System Quality & .136 & 052 & .145 & 2.619 & .009 & \\
\hline System Use & .274 & .044 & .332 & 6.284 & .000 & \\
\hline \multicolumn{6}{|c|}{ a. Dependent Variable: Training and Development } & \\
\hline \multirow[t]{2}{*}{ Model } & \multicolumn{2}{|c|}{$\begin{array}{l}\text { Unstandardized } \\
\text { Coefficients }\end{array}$} & \begin{tabular}{|c|}
$\begin{array}{r}\text { Standardized } \\
\text { Coefficients }\end{array}$ \\
\end{tabular} & \multirow[t]{2}{*}{$\mathrm{t}$} & \multirow[t]{2}{*}{ Sig. } & \multirow{2}{*}{$\begin{array}{c}\mathrm{R} \\
\text { Square }\end{array}$} \\
\hline & $\mathrm{B}$ & Std. Error & Beta & & & \\
\hline (Constant) & 1.044 & .195 & & 5.369 & .000 & \multirow{4}{*}{.349} \\
\hline Information Quality & .291 & .052 & .301 & 5.551 & .000 & \\
\hline System Quality & .189 & .060 & .165 & 3.118 & .002 & \\
\hline System Use & .229 & .051 & .228 & 4.517 & .000 & \\
\hline
\end{tabular}

Based on the previous results, it can be noted that the first sub-hypothesis of the second hypothesis "There is a statistically significant relationship between enterprise resource planning and training and development" is fully acceptable.

Based on the previous results, it can be seen that the second sub-hypothesis of the second hypothesis "there is a statistically significant relationship between enterprise resource planning and information exchange" is fully acceptable.

The correlation coefficient between enterprise resource planning was tested, including: (information quality, system quality, and system use) and recruitment and selection. It was found that there is a positive statistically significant correlation between the quality of information, the quality of the system, the use of the system, and the recruitment and selection, as the values of the correlation coefficient are $0.476,0.411$, and 0.425 , respectively, and the level of significance is less than 0.05 .

The correlation coefficient between enterprise resource planning was tested, including: (information quality, system quality, and system use) and compensation and benefits. It was found that there is a positive statistically significant correlation between the quality of information, the quality of the system, the use of the system, and compensation and benefits as the values of the correlation coefficient are 0.507, 0.432 , and 0.541 , respectively, and the level of significance is less than 0.05 .

Table 4 shows the multiple regression model for enterprise resource planning, including (information quality, system quality, and system use) and their impact on the dependent variable, which is recruitment and selection. The researcher found that there is a positive significant effect for both information quality, system quality, and system usage on Recruitment and selection as the significance level values are less than 0.05 and the regression coefficient values are $0.263,0.261$, and 0.194 , respectively. Moreover, its $R$ Square value is 0.282 , which means that $28.2 \%$ of recruitment and selection can be explained by information quality, system quality, and system utilization.

In addition, Table 4 shows the multiple regression model for enterprise resource planning, including (information quality, system quality, and system use) and their impact on the dependent variable, which is compensation and benefits. The researcher found that there is a positive significant effect for both information quality, system quality, and system usage on Compensation and benefits as the significance level values are less than 0.05 and the regression coefficient values are $0.215,0.101$, and 0.297 , respectively. Moreover, its $\mathrm{R}$ Square value is 0.369 , which means that $36.9 \%$ of compensation and benefits can be explained by information quality, system quality, and system utilization. 
Table 4: Regression Analysis for Enterprise Resource Planning on Recruitment and Selection, Compensation and Benefits

\begin{tabular}{|c|c|c|c|c|c|c|}
\hline \multirow[t]{2}{*}{ Model } & \multicolumn{2}{|c|}{$\begin{array}{l}\text { Unstandardized } \\
\text { Coefficients }\end{array}$} & \multirow{2}{*}{\begin{tabular}{|c|}
$\begin{array}{c}\text { Standardized } \\
\text { Coefficients }\end{array}$ \\
Beta \\
\end{tabular}} & \multirow[t]{2}{*}{$\mathrm{t}$} & \multirow[t]{2}{*}{ Sig. } & \multirow{2}{*}{$\begin{array}{r}\mathrm{R} \\
\text { Square }\end{array}$} \\
\hline & \begin{tabular}{|c|}
$\mathrm{B}$ \\
\end{tabular} & Std. Error & & & & \\
\hline (Constant) & 1.545 & .199 & & 7.781 & .000 & \multirow{4}{*}{.282} \\
\hline Information Quality & .263 & .054 & .280 & 4.916 & .000 & \\
\hline System Quality & .161 & .062 & .145 & 2.608 & .009 & \\
\hline System Use & .194 & .052 & .199 & 3.750 & .000 & \\
\hline \multicolumn{6}{|c|}{ a. Dependent Variable: Recruitment and Selection } & \\
\hline \multirow[t]{2}{*}{ Model } & \multicolumn{2}{|c|}{\begin{tabular}{|l|} 
Unstandardized \\
Coefficients
\end{tabular}} & $\begin{array}{l}\text { Standardized } \\
\text { Coefficients }\end{array}$ & \multirow[t]{2}{*}{$\mathrm{t}$} & \multirow[t]{2}{*}{ Sig. } & \multirow[t]{2}{*}{ R Square } \\
\hline & $\mathrm{B}$ & Std. Error & Beta & & & \\
\hline (Constant) & 1.536 & .164 & & 9.363 & .000 & \multirow{4}{*}{0.369} \\
\hline Information Quality & .215 & .044 & .260 & 4.869 & .000 & \\
\hline System Quality & .101 & .051 & .103 & 1.971 & .049 & \\
\hline System Use & 297 & .043 & .345 & 6.949 & .000 & \\
\hline
\end{tabular}

Based on the previous results, it can be seen that the third sub-hypothesis of the second hypothesis "There is a statistically significant relationship between enterprise resource planning and recruitment and selection" is fully acceptable.

Based on the previous results, it can be seen that the fourth sub-hypothesis of the second hypothesis "There is a statistically significant relationship between enterprise resource planning and compensation and benefits" is fully acceptable.

The correlation coefficient between enterprise resource planning was tested, including: (information quality, system quality, and system use), safety and health. It was found that there is a positive statistically significant correlation between the quality of information, the quality of the system, the use of the system, and safety and health as the values of the correlation coefficient are $0.477,0.490$, and 0.465 , respectively, and the significance level is less than 0.05 .

The correlation coefficient between enterprise resource planning was tested, including: (information quality, system quality, and system use) and employee relations. It was found that there is a positive statistically significant correlation between the quality of information, the quality of the system, the use of the system, and the relations between employees, as the values of the correlation coefficient are 0.461, 0.480 , and 0.446 , respectively, and the level of significance is less than 0.05 .

Table 5 shows the multiple regression model for enterprise resource planning, including (information quality, system quality, and system use) and their impact on the dependent variable, which is safety and health. Safety and health as the significance level values are less than 0.05 and the regression coefficient values are $0.155,0.245$, and 0.198 , respectively. Moreover, its $\mathrm{R}$ Square value is 0.327 , which means that $32.7 \%$ of safety and health can be explained by information quality, system quality, and system utilization.

In addition, Table 5 shows the multiple regression model for enterprise resource planning, including (information quality, system quality, and system use) and their impact on the dependent variable, which is relations between employees. The researcher found that there is a positive significant impact for both information quality, system quality, and system usage on employee relations where the significance level values are less than 0.05 and the regression coefficient values are 0.160, 0.291, and 0.196, respectively. Moreover, its R Square value is 0.320 , which means that $32 \%$ of employee relationships can be explained by information quality, system quality, and system utilization. 
Table 5: Regression analysis of enterprise resource planning on safety and health and Employee Relation

\begin{tabular}{|c|c|c|c|c|c|c|}
\hline \multirow[t]{2}{*}{ Model } & \multicolumn{2}{|c|}{$\begin{array}{l}\text { Unstandardized } \\
\text { Coefficients }\end{array}$} & \multirow{2}{*}{\begin{tabular}{|c|}
$\begin{array}{c}\text { Standardized } \\
\text { Coefficients }\end{array}$ \\
Beta \\
\end{tabular}} & \multirow[t]{2}{*}{$\mathrm{t}$} & \multirow[t]{2}{*}{ Sig. } & \multirow{2}{*}{$\begin{array}{r}\mathrm{R} \\
\text { Square }\end{array}$} \\
\hline & $\mathrm{B}$ & Std. Error & & & & \\
\hline (Constant) & 1.738 & .167 & & 10.393 & .000 & \multirow{5}{*}{.327} \\
\hline Information Quality & .155 & .045 & .189 & 3.441 & .001 & \\
\hline System Quality & .245 & .052 & .254 & 4.718 & .000 & \\
\hline System Use & .198 & .044 & .233 & 4.542 & .000 & \\
\hline \multicolumn{6}{|c|}{ a. Dependent Variable: Safety and Health } & \\
\hline \multirow[t]{2}{*}{ Model } & \multicolumn{2}{|c|}{ Unstandardized Coefficients } & $\begin{array}{l}\text { Standardized } \\
\text { Coefficients }\end{array}$ & \multirow[t]{2}{*}{$t$} & \multirow[t]{2}{*}{ Sig. } & \multirow[t]{2}{*}{ R Square } \\
\hline & $B$ & Std. Error & Beta & & & \\
\hline (Constant) & 1.396 & .184 & & 7.605 & .000 & \multirow{4}{*}{.320} \\
\hline Information Quality & .160 & .049 & .179 & 3.231 & .001 & \\
\hline System Quality & .291 & .057 & .276 & 5.105 & .000 & \\
\hline System Use & .196 & .048 & .212 & 4.105 & .000 & \\
\hline
\end{tabular}

Based on the previous results, it can be seen that the fifth sub-hypothesis of the second hypothesis "There is a statistically significant relationship between enterprise resource planning and safety and health" is fully acceptable.

Based on the previous results, it can be seen that the sixth sub-hypothesis of the second hypothesis "There is a statistically significant relationship between enterprise resource planning and employee relations" is completely acceptable. Based on these results, the second hypothesis "there is a statistically significant relationship between enterprise resource planning and human resource management practices" is fully acceptable.

Testing the Third Hypothesis of the Relationship between Human Resource Management Practices and Organizational Performance

The correlation coefficient between human resource management practices was tested, including: (Training and Development, Information Exchange, Recruitment and Selection, Compensation and Benefits, Safety and Health, And Employee Relations) and financial performance. It was found that there is a positive correlation with statistical significance between training and development, information exchange, employment and selection, compensation and benefits, safety and health, employee relations, and financial performance, as the values of the correlation coefficient are $0.455,0.510,0.465,0.445,0.503$, and 0.522. Respectively, and that the significance level is less than 0.05 .

The correlation coefficient between human resource management practices was tested, including: (training and development, information exchange, recruitment and selection, compensation and benefits, safety and health, and employee relations) and internal operations. It was found that there is a positive statistically significant correlation between training and development, information exchange, recruitment and selection, compensation and benefits, safety and health, employee relations, and internal operations as the values of the correlation coefficient are $0.381,0.467,0.422,0.439,0.370$, and 0.464 respectively and that the significance level is less than 0.05 .

Table 6 shows the multiple regression model for human resource management practices, including (training and development, information exchange, recruitment and selection, compensation and benefits, safety and health, and employee relations) and their impact on the dependent variable, which is financial performance. The researcher found that there is a positive moral impact for both training and development, information exchange, safety and health, and employee relations on financial performance where the significance level values are less than 0.05 and the regression coefficient values are $0.201,0.222$, 0.198 , and 0.208, respectively. While there is no significant effect for both Recruitment and selection, compensation and benefits on financial performance as the significance level values are greater than 0.05 . Moreover, the value of $\mathrm{R}$ Square is 0.382 , which means that $38.2 \%$ of financial performance can be explained through training and development, information exchange, safety and health, and employee relations. 
In addition, Table 6 shows the multiple regression model for human resource management practices, including (training and development, information exchange, recruitment and selection, compensation and benefits, safety and health, and employee relations) and their impact on the dependent variable, which is internal operations. The researcher found that there is a positive moral impact for both training and development, information exchange, and employee relations on internal operations, where the significance level values are less than 0.05 and the regression coefficient values are $0.143,0.181$, and 0.115 , respectively. While there is no significant effect for both recruitment and selection, compensation and benefits, Safety and health for internal operations as the significance level values are greater than 0.05 . Moreover, its R Square value is 0.303 , which means that $30.3 \%$ of internal operations can be explained through training and development, information exchange, and employee relations.

Table 6: Regression analysis of human resource management practices on financial performance and Internal Operations

\begin{tabular}{|c|c|c|c|c|c|c|}
\hline \multirow[t]{2}{*}{ Model } & \multicolumn{2}{|c|}{$\begin{array}{l}\text { Unstandardized } \\
\text { Coefficients }\end{array}$} & \multirow{2}{*}{\begin{tabular}{|c|}
$\begin{array}{c}\text { Standardized } \\
\text { Coefficients }\end{array}$ \\
Beta \\
\end{tabular}} & \multirow[t]{2}{*}{$\mathrm{T}$} & \multirow[t]{2}{*}{ Sig. } & \multirow{2}{*}{$\begin{array}{r}\mathrm{R} \\
\text { Square }\end{array}$} \\
\hline & $\overline{\mathrm{l}}$ & Std. Error & & & & \\
\hline (Constant) & & .244 & & 1.727 & .085 & \multirow{8}{*}{.382} \\
\hline Training and Development & & .066 & .152 & 3.065 & .002 & \\
\hline Information Exchange & & .062 & .205 & 3.581 & .000 & \\
\hline Recruitment and Selection & & .071 & .067 & 1.044 & .297 & \\
\hline Compensation and Benefits & & .075 & .010 & .163 & .871 & \\
\hline Safety and Health & & .077 & .155 & 2.567 & .011 & \\
\hline Employee Relations & & .072 & .177 & 2.900 & .004 & \\
\hline \multicolumn{6}{|c|}{ a. Dependent Variable: Financial Performance } & \\
\hline \multirow[t]{2}{*}{ Model } & \multicolumn{2}{|c|}{$\begin{array}{l}\text { Unstandardized } \\
\text { Coefficients }\end{array}$} & \begin{tabular}{|l|} 
Standardized \\
Coefficients
\end{tabular} & \multirow[t]{2}{*}{$\mathrm{t}$} & \multirow[t]{2}{*}{ Sig. } & \multirow[t]{2}{*}{ R Square } \\
\hline & $\mathrm{B}$ & Std. Error & Beta & & & \\
\hline (Constant) & 1.333 & .236 & & 5.656 & .000 & \multirow{7}{*}{.303} \\
\hline Training and Development & .143 & .063 & .119 & 2.263 & .024 & \\
\hline Information Exchange & .181 & .060 & .183 & 3.020 & .003 & \\
\hline Recruitment and Selection & .115 & .069 & .114 & 1.675 & .095 & \\
\hline Compensation and Benefits & .133 & .073 & .115 & 1.831 & .068 & \\
\hline Safety and Health & -.048 & .075 & -.041 & -.643 & .521 & \\
\hline Employee Relations & .196 & .069 & .184 & 2.840 & .005 & \\
\hline
\end{tabular}

Based on the previous results, it can be seen that the first sub-hypothesis of the third hypothesis "There is a statistically significant relationship between human resource management practices and financial performance" is partially acceptable.

Based on the previous results, it can be seen that the second sub-hypothesis of the third hypothesis "There is a statistically significant relationship between human resource management practices and internal operations" is partially acceptable.

The correlation coefficient between human resource management practices was tested, including: (training and development, information exchange, recruitment and selection, compensation and benefits, safety and health, and employee relations) and learning and growth. It was found that there is a positive statistically significant correlation between training and development, information exchange, employment and selection, compensation and benefits, safety and health, employee relations, and learning and growth as the values of the correlation coefficient are $0.372,0.544,0.436,0.503,0.503$, and 0.569 . Respectively, and that the significance level is less than 0.05 .

The correlation coefficient between human resource management practices was tested, including: (training and development, information exchange, recruitment and selection, compensation and benefits, safety and health, and employee relations) and customer satisfaction. It was found that there is a positive statistically significant correlation between training and development, information exchange, employment and selection, compensation and benefits, safety and health, employee relations, and customer 
satisfaction, as the values of the correlation coefficient are $0.396,0.416,0.376,0.408,0.428$, and 0.393 . Respectively, and that the significance level is less than 0.05 .

Table 7 shows the multiple regression model for human resource management practices, including (training and development, information exchange, recruitment and selection, compensation and benefits, safety and health, and employee relations) and their impact on the dependent variable, which is learning and growth. The researcher found that there is a positive moral impact for both information exchange, compensation, benefits, safety and health, and employee relations on learning and growth as the significance level values are less than 0.05 , and the regression coefficient valuesare $0.318,0.201,0.178$, and 0.309 , respectively. While there is no significant effect for both of Training, development, recruitment and selection for learning and growth as the significance level values are greater than 0.05 . Moreover, the value of $\mathrm{R}$ Square is 0.425 , which means that $42.5 \%$ of learning and growth can be explained by information sharing, compensation and benefits, safety and health, and employee relations.

In addition, Table 7 shows the multiple regression model for human resource management practices, including (training and development, information exchange, recruitment and selection, compensation and benefits, safety and health, and employee relations) and their impact on the dependent variable, which is customer satisfaction. The researcher found that there is a positive moral impact for information exchange, compensation and benefits, safety and health on customer satisfaction, as the significance level values are less than 0.05 and the regression coefficient values are $0.171,0.164$, and 0.204 , respectively. While there is no significant effect for both training and development, recruitment and selection, and relations between employees on customer satisfaction as the significance level values are greater than 0.05 . Moreover, the R Square value is 0.270 , which means that $27 \%$ of customer satisfaction can be explained by information sharing, compensation and benefits, and safety and health.

Table 7: Regression analysis of human resource management practices on learning, growth, and Customer

\begin{tabular}{|c|c|c|c|c|c|c|}
\hline \multirow[t]{2}{*}{ Model } & \multicolumn{2}{|c|}{ Unstandardized Coefficients } & \multirow{2}{*}{$\begin{array}{l}s \text { Standardized } \\
\text { Coefficients } \\
\text { Beta }\end{array}$} & \multirow[t]{2}{*}{$\mathrm{t}$} & \multirow[t]{2}{*}{ Sig. } & \multirow{2}{*}{$\begin{array}{r}\mathrm{R} \\
\text { Square }\end{array}$} \\
\hline & B & Std. Error & & & & \\
\hline (Constant) & .422 & .231 & & 1.825 & .069 & \multirow{8}{*}{.425} \\
\hline Training and Development & -.027 & .062 & -.021 & -.437 & .663 & \\
\hline Information Exchange & .318 & .059 & .298 & 5.411 & .000 & \\
\hline Recruitment and Selection & -.101 & .068 & -.092 & -1.487 & .138 & \\
\hline Compensation and Benefits & .201 & .071 & .162 & 2.821 & .005 & \\
\hline Safety and Health & 178 & .073 & .141 & 2.430 & .016 & \\
\hline Employee Relations & .309 & .068 & .267 & 4.545 & .000 & \\
\hline \multicolumn{6}{|c|}{ a. Dependent Variable: Learning and Growth } & \\
\hline \multirow[t]{2}{*}{ Model } & \multicolumn{2}{|c|}{$\begin{array}{l}\text { Unstandardized } \\
\text { Coefficients }\end{array}$} & \begin{tabular}{|l} 
Standardized \\
Coefficients
\end{tabular} & \multirow[t]{2}{*}{ t } & \multirow[t]{2}{*}{ Sig. } & \multirow[t]{2}{*}{ R Square } \\
\hline & $\mathrm{B}$ & Std. Error & Beta & & & \\
\hline (Constant) & 1.206 & .234 & & 5.154 & .000 & \multirow{8}{*}{.270} \\
\hline Training and Development & .207 & .063 & .178 & 3.299 & .001 & \\
\hline Information Exchange & .171 & .059 & .179 & 2.878 & .004 & \\
\hline Recruitment and Selection & -.024 & .068 & -.025 & -.356 & .722 & \\
\hline Compensation and Benefits & .164 & .072 & .147 & 2.278 & .023 & \\
\hline Safety and Health & .204 & .074 & .180 & 2.754 & .006 & \\
\hline Employee Relations & -.014 & .069 & -.014 & -.206 & .837 & \\
\hline \multicolumn{6}{|c|}{ a. Dependent Variable: Customer Satisfaction } & \\
\hline
\end{tabular}

Based on the previous results, it can be seen that the third sub-hypothesis of the third hypothesis "There is a statistically significant relationship between human resource management practices and learning and growth" is partially acceptable.

Based on the previous results, it can be seen that the fourth sub-hypothesis of the third hypothesis "There is a statistically significant relationship between human resource management practices and customer satisfaction" is partially acceptable. Based on these results, the third hypothesis "there is a 
statistically significant relationship between human resource management practices and organizational performance through the balanced scorecard" is partially acceptable.

Testing the Fourth Hypothesis of the Role of Human Resource Management Practices in the Relationship Between Enterprise Resource Planning and Organizational Performance through the Balanced Scorecard

The multiple regression model test of human resource management practices on financial performance, and it was found that training and development, information exchange, safety and health, and employee relations could play the role of mediator between enterprise resource planning and financial performance because there is a direct relationship between them. Based on the results of the first hypothesis, it was found that there is a statistically significant relationship between enterprise resource planning and organizational performance through the balanced scorecard. The training and development were found to moderate the relationship between system use and financial performance in its entirety, while it partially mediates the relationship between information quality, system quality, and financial performance.

The information exchange was found to moderate the relationship between system use and financial performance in its entirety, while it partially moderates the relationship between information quality, system quality, and financial performance.

The safety and health were found to moderate the relationship between system use and financial performance in its entirety, while it moderates the relationship between information quality, system quality, and financial performance in part.

The employee relations were found to moderate the relationship between system use and financial performance as a whole, while it partially moderates the relationship between information quality, system quality, and financial performance.

The results of the multiple regression model test of human resource management practices on internal operations, and it has been shown that training and development, information exchange, and employee relations can play the role of mediator between enterprise resource planning and internal operations because there is a direct relationship between them. Based on the results of the first hypothesis, it was found that there is a statistically significant relationship between enterprise resource planning and organizational performance through the balanced scorecard. The training and development were found to moderate the relationship between system quality and internal operation in whole, while it partially mediates the relationship between information quality, system use, and internal operation.

The information exchange was found to moderate the relationship between information quality, system quality and internal operations in its entirety, while it partially moderates the relationship between system use and internal operations.

The information exchange was found to mediate the relationship between information quality, system quality and internal operations in its entirety, while it partially moderates the relationship between system use and internal operations.

The employee relations were found to moderate the relationship between system quality and internal operations in whole, while it partially moderates the relationship between information quality, system use, and internal operation.

The results of the multiple regression model test for human resource management practices on learning and growth, and it has been shown that information exchange, compensation and benefits, safety and health, and employee relations can play the role of mediator between enterprise resource planning and learning and growth because there is a direct relationship between them. Based on the results of the first hypothesis, it was found that there is a statistically significant relationship between enterprise resource planning and organizational performance through the balanced scorecard. The information exchange was found to moderate the relationship between information quality, system quality and learning and growth as a whole, while it partially mediates the relationship between system use, learning and growth.

The compensation and benefits partially was found to moderate the relationship between information quality, system quality, system use, and learning and growth. 
The safety and health were found to moderate the relationship between system quality and learning and growth as a whole, while it partially moderates the relationship between information quality, system use, and learning and growth.

The relationships among employees were found to moderate the relationship between system quality and learning and growth as a whole, while it partially moderates the relationship between information quality, system use, and learning and growth.

The results of the multiple regression model test of human resource management practices on client satisfaction, and it has been shown that training and development, information exchange, compensation and benefits, and safety and health can play the mediating role between enterprise resource planning and customer satisfaction because of a direct relationship between them. Based on the results of the first hypothesis, it was found that there is a statistically significant relationship between enterprise resource planning and organizational performance through the balanced scorecard. The training and development were found to moderate the relationship between information quality and customer satisfaction in its entirety, while it mediates the relationship between system quality, system use, and partial customer satisfaction.

The information exchange was found to moderate the relationship between information quality and customer satisfaction as a whole, while it moderates the relationship between system quality, system use, and partially customer satisfaction.

The compensation and benefits were found to moderate the relationship between information quality and overall customer satisfaction, while it moderates the relationship between system quality, system use, and partial customer satisfaction.

The safety and health were found to moderate the relationship between information quality, system quality, and customer satisfaction in its entirety, while it moderates the relationship between system use and customer satisfaction in part.

Based on these results, the fourth hypothesis, "There is a statistically significant role for human resource management practices in the relationship between enterprise resource planning and organizational performance through the balanced scorecard" is partially acceptable.

\section{Conclusion, Recommendation and Limitations}

This study aims to examine the impact of enterprise resource planning (information quality, system quality, system use) and human resource management practices (training and development, information exchange, recruitment and testing, compensation and benefits, safety and health, employee relations) on organizational performance through the scorecard Balanced (financial performance, customer performance, supplier performance, employee performance). To test this goal, the researcher used the classical philosophy in this study and the inductive approach because they are more compatible with the nature of the research and with what the researcher wants to reach. Consequently, the data required to test the goal of the study was collected through the quantitative data issued from the questionnaire that was distributed to collect the required data by workers in the armature sector companies. Statistical methods such as: correlation and structural equation model will be used. Each of the measures of validity and reliability are also used, and the truthfulness and reliability of the data are intended as two important conditions that must be fulfilled and available to start using the available data to respond to the research hypotheses.

The recommendations of the current research are that the research should focus on other variables that affect the institutional performance. The research data was collected through a questionnaire distributed to workers in the rebar sector companies. This research contains many recommendations that may be useful for future research. First, a longitudinal study is recommended to achieve better results, as time was one of the barriers in this study. Future research could also look at companies other than armament companies. Future research will be able to have a better timeframe to be able to collect a larger sample as well as follow the technique of random sampling. More future research is needed to explore the role of the balanced scorecard and human resource management practices in order to gain a general understanding of the links between ERP and corporate performance. Finally, a comparative study can be made to compare the factors that affect institutional performance in developed and developing countries. 
This research has several limitations through the study that I covered. First, despite the fact that the researcher collected data from armament companies only, the research was limited to taking into account more companies in other sectors. In addition, the second limitation of this research is the time limit to finish the research, which was a hindrance to collecting a larger sample size to represent the data under study. The third limitation was the small number of sample size used in the questionnaires collected, which pushed them to the blanket count method.

\section{Reference}

Al-Najjar, S.M. and Kalaf, K.H., 2012. Designing a balanced scorecard to measure a bank's performance: A case study. International journal of business administration, 3(4), p.44.

Anderson, M., Banker, R.D., Menon, N.M. and Romero, J.A., 2011. Implementing enterprise resource planning systems: organizational performance and the duration of the implementation. Information Technology and Management, 12(3), pp.197-212.

Al-Dhaafri, H.S. and Al-Swidi, A.K., 2014. The entrepreneurial orientation and the organizational performance: Do enterprise resource planning systems have a mediating role? A study on Dubai police. Asian Social Science, 10(2), p.257.

Shen, Y.C., Chen, P.S. and Wang, C.H., 2016. A study of enterprise resource planning (ERP) system performance measurement using the quantitative balanced scorecard approach. Computers in Industry, 75, pp.127-139.

Saleh, T. and Thoumy, M., 2018, March. The impact of ERP systems on organizational performance: in Lebanese wholesale engineering companies. In 2018 7th International Conference on Industrial Technology and Management (ICITM) (pp. 198-204). IEEE.

Kushwaha, P., Yadav, P. and Prasad, J., 2018. Impact of enterprise resource planning on human resource management in automobile sector: Statistical analysis. Journal of Statistics and Management Systems, 21(4), pp.601-615.

Widjaja, H.A.E., Fernando, E., Grady, D., Liejaya, B. and Siwi, M.P., 2019, October. Development and Validation of Instruments for Evaluation Enterprise Resource Planning on Human Resource Management in Higher Education Sector. In 2019 3rd International Conference on Informatics and Computational Sciences (ICICoS) (pp. 1-6). IEEE.

Quresh, T.M., Akbar, A., Khan, M.A., Sheikh, R.A. and Hijazi, S.T., 2010. Do human resource management practices have an impact on financial performance of banks? African Journal of Business Management, 4(7), pp.1281-1288.

Subramaniam, C., Shamsudin, F.M. and Ibrahim, H., 2011. Linking Human Resource Practices and Organisational Performance: Evidence from Small and Medium Organisations in Malaysia. Jurnal Pengurusan, 32, pp.27-37.

Hassan, M., Hassan, S., Khan, M.F.A. and Iqbal, A., 2013. Impact of HR practices on employee satisfaction and employee loyalty: An empirical study of government owned public sector banks of Pakistan. Middle East Journal of Scientific Research, 16(1), pp.01-08.

Al-Tit, A.A., 2016. The mediating role of knowledge management and the moderating part of organizational culture between HRM practices and organizational performance. International Business Research, 9(1), p.43.

Wikhamn, W., 2019. Innovation, sustainable HRM and customer satisfaction. International Journal of Hospitality Management, 76, pp.102-110.

Lin, H.F., 2015. Linking knowledge management orientation to balanced scorecard outcomes. Journal of Knowledge Management.

Albrecht, S.L., Bakker, A.B., Gruman, J.A., Macey, W.H. and Saks, A.M., 2015. Employee engagement, human resource management practices and competitive advantage. Journal of Organizational Effectiveness: People and Performance.

Parto, A., Sofian, S. and Saat, M.M., 2016. The impact of enterprise resource planning on financial performance in a developing country. International Review of Management and Business Research, 5(1), p.176.

Khan, F.H., 2019. The impact of Enterprise Resource Planning (ERP) system on organizational performance in DDC.

Guimaraes, T., Armstrong, C., Dutra de Oliveira Neto, J., Riccio, E.L. and Madeira, G., 2015. ASSESSING THE IMPACT OF ERP ON END-USER JOBS. International Journal of the Academic Business World, 9(1). 